\title{
ARTIFICIALLY CONTAMINATED OPEN TIBIAL FRACTURES - THERAPY WITH CLOXACILLIN SODIUM
}

\author{
LEŠIĆ $A^{*}$, BUMBAŠIREVIĆ $M^{*}$, BUMBAŠIREVIĆ $V^{*}$, KRSTIĆ $\mathrm{N}^{* *}$ and TATIĆ $\mathrm{V}^{* * *}$ \\ *Institute for Orthopaedic Surgery and Traumatology, School of Medicine, Belgrade, \\ ** Department of Radiology, Faculty of Veterinary Medicine, Belgrade, \\ *** Institute for Pathology, School of Medicine, Banja Luka, Republika Srpska
}

Three methods of treatment by Cloxacillin were applied for the prevention of deep infection of bones after artificial contamination of fractured rat tibia, with Staphylococcus aureus. Thus, combined intramedullary and parenteral therapy was compared with intramedullary administration only and parenteral therapy only.

Intramedullary injection of $15 \mathrm{mg}$ Cloxacillin (dissolved in water) during surgical management of the fracture and postoperative parenteral treatment with the same antibiotic in a dose of $50 \mathrm{mg} / \mathrm{kg} /$ day over 14 days prevented the development of staphylococcal infection in all animals $(n=21)$. Cloxacillin parenteral treatment only achieved a therapeutical effect after 42 days of application in a dose of $50 \mathrm{mg} / \mathrm{kg}$. A single, intramedullary injection of $15 \mathrm{mg}$ aqueous solution of Cloxacillin failed to prevent completely the staphylococcal infection. This therapy was relatively successful till postoperative day 28 , namely, there were only $16.6 \%$ of positive results for S. aureus in relation to $40 \%$ on day 42 after the surgery.

Gross, radiological and histological changes of the operated tibia of rats were correlated to the effects of the therapy applied. The results of our studies suggest that, in open tibial fractures, parenteral therapy together with intramedullary administration of antibiotics may prevent the development of infection and shorten the parenteral therapy by a direct effect on the contaminated injury during the first few postoperative days.

Key words: experimental model, tibial fracture, infection, therapy

\section{INTRODUCTION}

In orthopedic surgery, open fractures of the lower leg are a very frequent therapeutical problem because of possible development of infection and osteomyelitis. In spite of a suitable approach to the management of open fractures, i.e. fast diagnostics, early surgical wound management, and fracture stabilization, infections requiring long-term treatment are very frequent (Court Brown et al., 1996; Leassus et al., 2000; Hutchins et al., 2000).

In order to explain the development of posttraumatic osteomyelitis and its sequelae as well as the efficiency of the treatment applied, a considerable number 
of studies on experimental laboratory animals (rodents and dogs) have been carried out. These artificial fractures and artificial bacterial contamination of the bones have served as models (Passl et al., 1984; Norden and Kennedy, 1970; Norden et al., 1980). Different antibiotics were used for the prevention and therapy of experimentally induced osteomyelitis. They were applied parenterally or in the form of depot preparations that were injected into the medullary canal at the fracture site (Norden and Shinners, 1985; Jacob et al., 1991; Perry, 1991; Garvin et al., 1994). The studies revealed that parenteral antibiotic therapy is not always efficient either for prevention or treatment of experimental posttraumatic osteomyelitis (Norden, 1978; Nelson et al., 1990; Jacob et al., 1991). Believing that a longer time was needed to achieve a therapeutical effect in bones with parenteral antibiotic administration, Jacob et al. (1991) and Garvin et al. (1994) applied local-intramedullary antibiotic injections for the prevention and treatment of osteomyelitis, and they obtained a complete cure of bone infection in stabilized fractures. However, Fitzgerald et al. (1983) and Petri (1991) concluded that local antibiotic treatment was more effective for prevention than for treatment of posttraumatic osteomyelitis.

In our clinical cases of osteomyelitis developed after open fractures, Staphylococcus aureus was most commonly isolated. This staphylococcus was also recorded as the cause of nosocomial sepsis and surgical field infection (Jovanovic et al., 2003). Bearing in mind that parenteral treatment only as well as local-intramedullary therapy solely were not always successful for the prevention and treatment of osteomyelitis, we believed it would be intriguing to investigate a a cobination treatment. A artificial fractures of rat tibia were contaminated by a common strain of Staphylococcus aureus as a model. For prevention of deep infection of the bones, three methods of treatment with the antibiotic Cloxacillin were compared: 1. combined intramedullary and parenteral therapy 2 . intramedullary injection only, and 3. parenteral therapy only. The success of the modes of treatment applied was estimated on the basis of the results obtained from clinical, microbiological, radiological and pathohistological examinations.

\section{MATERIAL AND METHODS}

Experimental animals. Wistar male rats, weighing $200-250 \mathrm{~g}$, were used in the experimental model of treatment of artificially contaminated tibial fractures. The animals were kept in individual cages and fed in accordance with the regulations for care and use of laboratory animals (4).

Surgical procedure. The previously described procedures (Nelson et al; 1990), were modified with the intention to simulate a natural accidental open fracture by an artificial break, after peritoneal anesthesia by thiopental sodium ( $5 \mathrm{mg} / 100 \mathrm{gr})$. The operation was performed under sterile conditions. The right leg was shaved and scrubbed with alcohol and Betadine. Following the $1-1.5 \mathrm{~cm}$ long anterolateral tibial skin incision, and division of the lateral muscles, the medial tibia was stripped and thereafter a transverse fracture was made by a small chisel-like knife (osteotome). The medullary canal was surgically managed, while the 
fracture site was fixed with a Kirschner nail $(1.5 \mathrm{~mm})$ that corresponded to Ender's pins in human medicine (Sisk, 1987; Chapman, 1991).

Intramedullary inoculation of bacterial suspension and application of antibiotics. A bacterial suspension of Staphylococcus aureus - strain 6538P ATCC (American Type Culture Collection) was prepared in trypticase soy broth (TSB). Densiometry of the bacterial suspension was carried out using a McFarland nephelometer and a standard of $5 \times 10^{6}$ staphylococci $/ \mathrm{ml}$. After centrifugation, the sediment was resuspended to obtain $5 \times 10^{6}$ colony forming units (CFU) per $100 \mu \mathrm{l}$ of the inoculum. Following the fixation, and prior to closure of the surgical wound, $100 \mu \mathrm{l}$ of bacterial suspension was injected through a needle $0.6 \times 25 \mathrm{~mm}$ in diameter that had been placed during the operation. Thereupon, $15 \mathrm{mg}$ of aqueous solution of Cloxacillin sodium was injected through the same needle in two experimental groups (A and B). After the needle was removed, the lower leg incision was closed by absorbable sutures.

Experimental design - therapeutical trials. All animals, with open and fixed fractures of the right tibia, whose medullary canal was inoculated with Staphylococcus aureus, were divided into 4 experimental groups: A, B, C, and DC. Groups A, B, and C were treated with Cloxacillin (Sweetman, 2002). Group DC was given no therapy. Initially, all groups consisted of 21 experimental animals, and they were divided into 3 subgroups containing 7 animals each. One third of surviving animals from each group was sacrificed on day 28, 42 and 66 after the surgery (Table 1).

Table 1. Experimental design - therapeutical trials

\begin{tabular}{|l|l|c|c|}
\hline $\begin{array}{c}\text { Experimental } \\
\text { groups }\end{array}$ & \multicolumn{1}{|c|}{$\begin{array}{c}\text { Therapy with } \\
\text { *Cloxacillin }\end{array}$} & $\begin{array}{c}\text { Duration of therapy - } \\
\text { days }\end{array}$ & $\begin{array}{c}\text { Sacrifice of survived } \\
\text { animals }- \text { days }\end{array}$ \\
\hline A $\quad(n=21)$ & $\begin{array}{l}15 \mathrm{mg} / \mathrm{in} 200 \mu \mathrm{l} \text { water sol. } \\
\text { intramedullary and } \\
50 \mathrm{mg} / \mathrm{kg} / 8 \mathrm{~h}, \mathrm{sc}\end{array}$ & $\begin{array}{c}\text { On operative day and } \\
\text { during } 14,28 \text { and } 42 \\
\text { days }\end{array}$ & $28,42,66$ \\
\hline B $(n=21)$ & $\begin{array}{l}15 \mathrm{mg} / \mathrm{in} 200 \mu \mathrm{l} \text { water sol } \\
\text { intramedullary }\end{array}$ & On operative day & $28,42,66$ \\
\hline C $(\mathrm{n}=21)$ & $50 \mathrm{mg} / \mathrm{kg} / 8 \mathrm{~h}, \mathrm{sc}$ & 14,28 and 42 & $28,42,66$ \\
\hline DC $(n=21)$ & No therapy & 14,28 and 42 & $28,42,66$ \\
\hline
\end{tabular}

*Cloxacillin Sodium -1,09 monograph substance in $1 \mathrm{~g}$ anhidrou cloxacillin (Cloxipen- Beecham) 
Clinical examination. The health of the rats was monitored by measuring the body weight and body temperature, during the first seven days and afterwards once a week. Gross pathological changes of the operated tibia were classified according to Nelson et al., (1990) using a semiquantitative scale ranging from 0-4. " 0 " - no changes; " 1 " - only erythema without any other changes; " 2 " - erythema, tibial shaft thickening, new bone formation; " 3 " - abscess with new bone formation, fistula or purulent exudate; and " 4 " - severe bone destruction, abscess involving at least $50 \%$ of the tibia.

Microbiological testing. After the animals were sacrificed, the bone tissue from the fracture site was sampled out, under aseptic conditions, for bacteriological examination. The finding of Staphylococcus aureus colonies, minimum one, in the bacteriological culture medium indicated persistent bone infection and inadequate treatment.

Radiological evaluation. Radiological evaluation was based on anteroposterior and lateral views of the operated tibia after the rats were sacrificed. The reactions of the periosteum, formation of callus and sequestra, bone destruction and development of disease, were all monitored radiographically.

Pathohistological evaluation. Following the sacrifice of the animals, the whole tibia was amputated. Bone sections were sliced, fixed in $10 \%$ buffered formaldehyde, placed in paraffin molds, and then cut by microtome in slices 5$7 \mu \mathrm{m}$ thick. The preparations were stained by the standard histological methods: hematoxylin-eosin.

\section{RESULTS}

\section{Clinical results}

Loss of body weight was noted in all animals during the first seven days after surgery. During this period, body temperature was slightly increased in groups A, $B$ and $C$ that were treated with antibiotics, while it was extremely high in the untreated group $\mathrm{DC}$, ranging from $39^{\circ}-40^{\circ} \mathrm{C}$.

The results of gross examination of the operated tibias revealed that changes, according to the Nelson semiquantitative scale, ranged from " 0 " to " 2 ", in the treated groups $A, B$ and C, i.e. no changes or insignificant erythema and thickening of the tibial shaft (lower leg circumference). On postoperative day 42, an abscess accompanied with new bone formation was manifested in one animal from group B, giving an intramedullary injection of Cloxacillin (score "3"). The scores of gross changes in the untreated group D-C ranged from " 3 " to " 4 ", which suggested the presence of abscesses, fistulae and bone destruction in the operated tibia (Table 2).

On day 28 after the operation, the mean value of the score for gross changes in the operated tibia showed, according to the Mann-Whitney test, that there was no difference between the treated groups A, B and C. However, the differences between these three groups and group D-C (no therapy) were significant $(p<0.001$ and $p<0.005)$. In the second postoperative observation 
Acta Veterinaria (Beograd), Vol. 54, No. 5-6, 457-466, 2004.

Lešić A et al. Artificially contaminated open tibial

fractures - therapy with Cloxacillin sodium

period, on day 42, groups $A$ and $C$ remained differentiated from group DC $(p<0.005)$, while the results were worse in group B and were close to those for group DC $(p>0.05)$. A significant difference was found between groups A and C, and group $B(p<0.005)$. On day 66 , all mean score values for groups $A, B$ and $C$ were better than in group DC (Figure 1).

Table 2. Scores for gross (macroscopic and bacteriological) findings in the operated tibias of the experimental rats

\begin{tabular}{|c|c|c|c|c|}
\hline Group & $\begin{array}{c}\text { Day of } \\
\text { sacrifice }\end{array}$ & $\begin{array}{c}\text { Survived } \\
\text { animals No }\end{array}$ & $\begin{array}{c}\text { Gross tehnology } \\
\text { score* / No of } \\
\text { animals }\end{array}$ & $\begin{array}{c}\text { Positive bone } \\
\text { culture } \\
\text { No - \% }\end{array}$ \\
\hline A & \multirow{4}{*}{28} & 7 & "1"/6 and "2"/1 & $0-0$ \\
\hline$B$ & & 6 & "1"/2 and "2"/4 & $1-16,6$ \\
\hline C & & 6 & "1"/3 and "2"/3 & $1-16,6$ \\
\hline $\mathrm{DC}$ & & 3 & “3"/3 & $3-100$ \\
\hline A & \multirow{4}{*}{42} & 7 & "0"/3 and "1"/4 & $0-0$ \\
\hline B & & 5 & "2"/4 and "3"/1 & $2-40$ \\
\hline C & & 6 & "0"/3 and "1"/3 & $1-16,6$ \\
\hline $\mathrm{DC}$ & & 2 & “3”/2 & $1-50$ \\
\hline A & \multirow{4}{*}{66} & 7 & "0"/5 and "1"/2 & $0-0$ \\
\hline$B$ & & 5 & "1"/2 and "2"/3 & $1-16,6$ \\
\hline C & & 7 & "1"/6 and "2"/1 & $0-0$ \\
\hline $\mathrm{DC}$ & & 4 & "3"/2 and "4"/2 & $3-75$ \\
\hline
\end{tabular}

*legend in the text

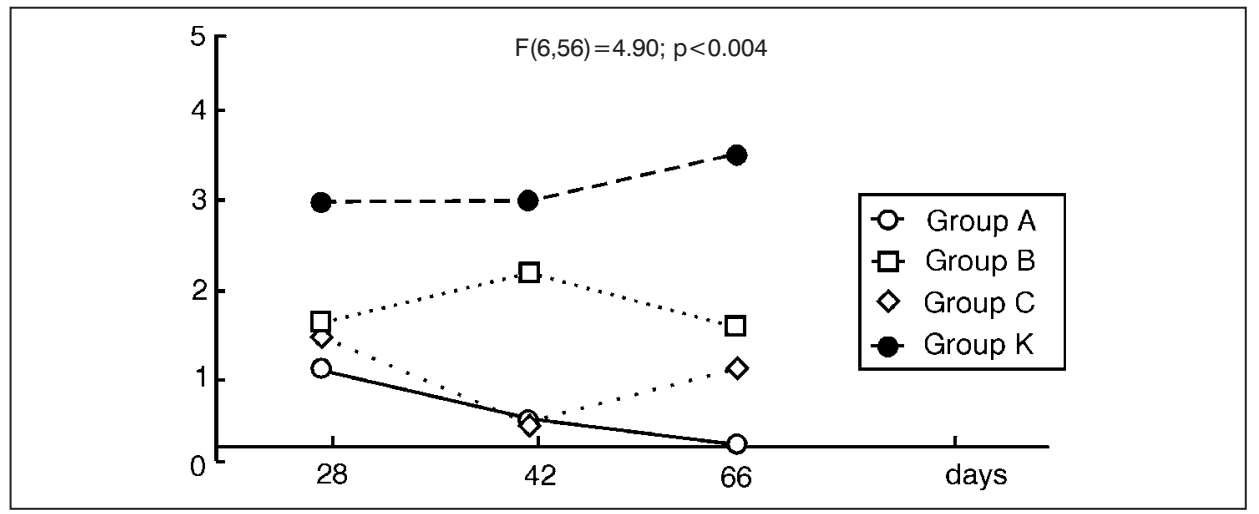

Figure 1. Mean score values for the studied animals 


\section{Bacteriological examination}

Bacteriological examination of the specimens of operated tibial bones taken from all surviving animals $(n=21)$ of group $A$, treated by combined parenteral and intramedullary antibiotic therapy revealed no Staphylococcus aureus. In the 16 surviving animals of group $B$, treated only by an intramedullary injection of Cloxacilline, S. aureus was isolated in $4(25 \%)$ bone specimens. In group C, given parenteral therapy for 14,28 or 42 days, S.aureus was recovered in $2(10.5 \%)$ of the 19 surviving animals. In group DC, without antibiotic therapy, 9 animals survived until day 66 after the surgery. S.aureus was isolated in $8(88.8 \%)$ tibial specimens (Table 2).

Statistical analysis by Fisher's test showed that, 28 days after the surgery, there was no significant difference between the treated groups $A, B$ and $C$ $(p>0.05)$ regarding the extent of infection in relation to the therapy applied (mode of treatment). All three groups were significantly distinguished from the untreated group DC $(p<0.005)$. After 28 days therapy (time of sacrifice - day 42$)$, a significant effect was achieved in groups $A$ and $C$ in comparison with group $B$. No significant difference in the extent of infection was found after 42 days therapy in groups $A$ and $C$ (sacrifice on day 66 ). Nevertheless, there was a significant difference between groups $\mathrm{A}$ and $\mathrm{C}$, and group $\mathrm{B}$.

Radiological analysis

Radiographic examination confirmed that the Kirschner wire was in place in the operated animals from groups $A, B$ and $C$ (Figure 2). The degree of bone union at the fracture site was the most prominent in group $A$, and somewhat

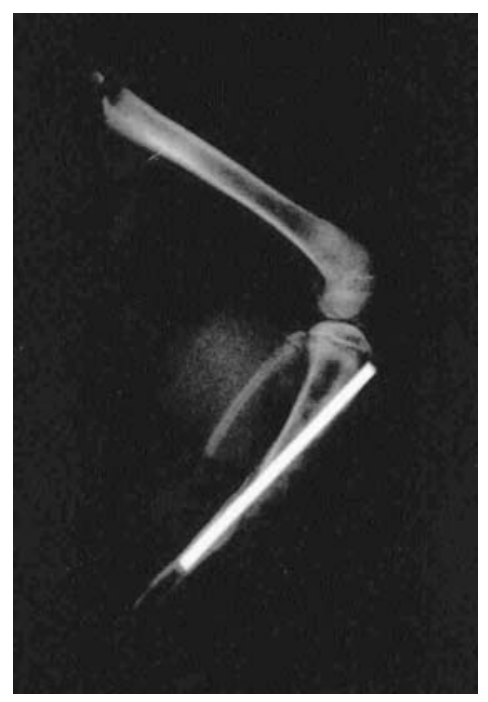

Figure 2. Radiography of an operated tibia from group $A$, on day 66 , showing sanation at the fracture site delayed healing was noted in group $C$ (not before day 66 after the operation).

In group DC, without antibiotic treatment, radiography revealed apparent osteolysis, with wire migration and necrotic bone. Signs of osteomyelitis were evident on the X-ray film.

The criteria according to Nelson et al. (1990), used for evaluation of gross pathology in the operated tibias (Table 2), correlated with the reported radiological changes.

Pathohistological analysis

Pathohistological analysis showed a minor inflammatory process in the groups treated with Cloxacillin. In these groups, especially in groups $A$ and $C$, lymphocytic infiltrates neither passed through the metaphyseal plate nor entered the joint space. Histologically, newly formed callus bone was the most marked in group $A$, with connective tissue filling the fracture line. On day 28 after surgery, this had transformed into young bone 
tissue with disoriented trabeculas (Figure 3). In group DC, without antibiotic therapy, lymphocytic infiltrates penetrating the metaphyseal plate were detected in two animals on day 66 after the operation. In rats of this group, the fracture line unfilled with bone tissue persisted for some time.

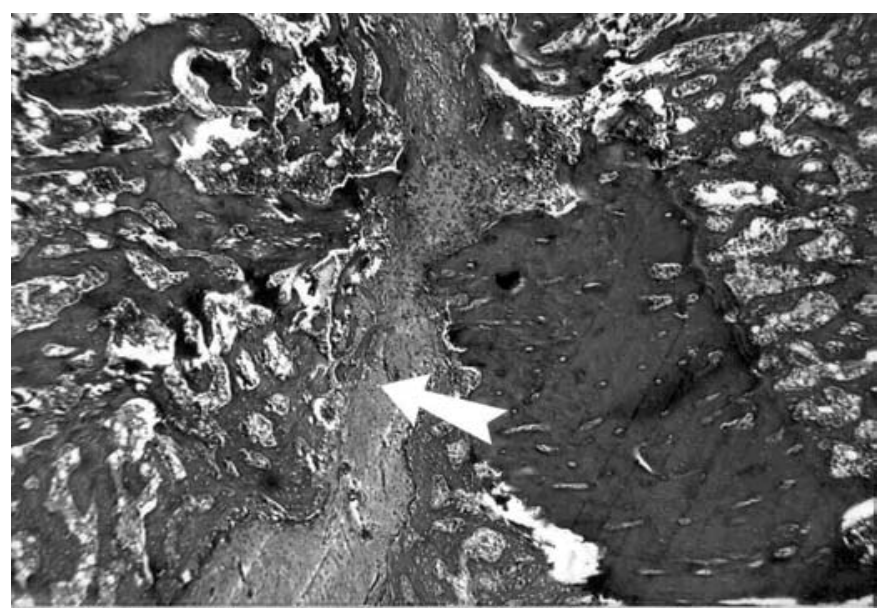

Figure 3. Pathohistological specimen of a operated tibia from group A, showing young new bone formation (arrow), Hematoxyllin Eosin staining, magnification 10x10

\section{DISCUSSION}

Recent studies on experimental models of artificial fractures and osteomyelitis developing after bacterial inoculation, have enabled the application and evaluation of different methods of surgical and medicamentous treatment (Nunmaker, 1998; Rissing et al., 1985; Dahners and Funderburk, 1974).

Our option for the cause of infection in this experimental model was Staphylococcus aureus, as in human orthopedic surgery it is, the cause of infection in $37.5 \%$ of open tibial fractures (Klemm, 1980). In addition, since this infection is most frequently seen in the lower extremities, the tibia of the rat was used as a model. In contaminated fractures, early administration of antibiotics is extremely important, in order to prevent osteomyelitis in $3^{\text {rd }}$ degree open fractures where the infection develops in $50 \%$ of cases (Nunmaker, 1998; Chanda et al., 1996; Hutchins et al., 2000).

In order to minimize the systemic intoxication that is often associated with long-term antibiotic treatment, Klemm (1980), Perry and Pearson (1991) and Garvin et al., (1994) recommended local intramedullary therapy. Different delivery systems have been used for more effective and successful effects of local antibiotics. Garvin et al. (1994) succeeded to manage completely the stabilized staphylococcal osteomyelitis of canine tibia using a polylactide/polyglycolideentamicin implant. Using bone allografts with added antibiotics, Petri (1991) 
achieved fast healing and prevention of staphylococcal infection of artificial fractures of rabbit mandible. The studies by Klemm (1980), Mackey et al. (1982) and Walenkamp et al.(1986) showed that the application of antibiotics at the site of injury resulted in a high concentration of the drug and its rapid action, in contrast to systemic treatment.

Our studies on the effectiveness of three therapeutical methods for the prevention of osteomyelitis, in the model of staphylococcal contamination of artificial fractures of rat tibia, verified that an intramedullary injection of Cloxacillin, during surgical management of the fracture, along with postoperative parenteral treatment with the same antibiotic, for 14 days, prevented S.aureus infection in all tested animals.

Parenteral therapy alone with Cloxacillin for 14 or 28 days after the surgery, failed to prevent the development of staphylococcal infection of the tibial fracture in the $16.6 \%$ of the animals at both times. However, after 42 days of treatment with Cloxacillin, bacteriological findings in all surviving animals $(n=7)$ were negative.

Application of Cloxacillin to the medullary canal only did not completely prevent staphylococcal infection at any of the times examined. This therapy was fairly effective until day 28 after the operation, because positive results were found in only $16.6 \%$ of the animals in relation to $40 \%$ of positive animals on day 42 from the surgery. Although Cloxacillin injected intramedullarlily was relatively shortacting, its effect in group $A$, which was given combined intramedullary and parenteral therapy, shortened considerably the time for successful parenteral treatment, that is, 14 days in comparison with the 42 days necessary to manage the infection by parenteral treatment only.

Employing 14-day parenteral ampicillin anhydrate therapy, Jacob et al (1991) prevented staphylococcal osteomyelitis in all treated rabbits. An intramedullary injection of microencapsulated ampicillin was also very effective, while the intramedullary therapy with an aqueous solution of ampicillin prevented the infection in 3 out of 4 treated animals.

Gross pathological changes of the operated tibia were correlated with the effects of therapy. Scores of " 3 " and "4" (Nelson, 1990) were recorded in animals of the control untreated group and in a single rat from the group given intramedullary therapy only, always indicating the presence of S.aureus in the bones.

The verified radiological and histological changes in the rat tibia (extensive bone destruction and fracture line without bone tissue filling) were almost identical to the changes reported in persons with untreated or inadequately treated fractures of the lower leg (Chapman 1991; Sisk 1987.).

The results of our study suggest that open tibial fractures require fast and thorough surgical wound management, fixation-stabilization of the fracture and combined intramedullary-local and parenteral, systemic treatment. A direct effect of antibiotics on a contaminated injury may be achieved by intramedullary treatment, and together with parenteral therapy during the first postoperative days (hours), the development of infection may be prevented, until the drug susceptibility test is obtained and an adequate treatment is introduced -target therapy (Harley et al; 2002). The use of a carrier that will release the antibiotic for a 
longer period and consequently prolong its effect would be helpful for the treatment of chronic osteomyelitis, while in the initial treatment of open fractures, the application of aqueous suspensions of certain antibiotics (Cloxacillin) is quite acceptable.

Address for corresspondence:

Dr Aleksandar Lešić,

Hadzi Melentijeva 8, 11000 Beograd,

Serbia\&Montenegro

e-mail: alelesic@Eunet.yu

\section{REFERENCES}

1. Chanda HS, Fitzgerald RH, Wieter P, Sud S, Nasser S, Wolley PH, 1996, Experimental acute hematogenous osteomyelitis in mice. Histopathological and immunological findings, $J$ Orthop Res, 17,3, 376-81.

2. Chapman MW, 1991, Open Fractures in Rockwood Geen's Fractures in Adults (223-257), JB Lippinott Co. New York, London, Philadelphia.

3. Court-Brown MC, McQueen MM, Quaba AA, 1996, Management of Open Fractures, Martin Dunitz, Mosby.

4. Committee on the Care and Use of Laboratory Animals, 1985 NIH Publication. Washington DC, US Public Health Service, 86, 23.

5. Dahners LE, Funderburk CH, 1987, Gentamicin-loaded plaster of paris in a treatment of experimental osteomyelitis in rabbits, Clin Orth, 219, 278.

6. Fitzgerald RH Jr, 1983, Experimental Osteomyelitis: description of a canine model and role of depot administration of antibiotics in the prevention and treatment of sepsis, J Bone Joint Surg , 65A:371-80

7. Garvin KI, Miyano JA, Robinson D, Giger D, Novak J, Radio S, 1994, Polylactide/Polyglycolide antibiotic implants in the treatment of osteomyelitis, a canine model, $J$ Bone Joint Surg, 76A, 1500-06.

8. Harley B, Beapure LA, Jones CA, Dulai SK, Weber DW, 2002, The effect of time to definitive treatment on the rate of nonunion and infection in open fractures, $J$ Orthop Traum 16,7, 484-90.

9. Hutchins CM, Sponeseller $P D$, Sturm P, Mosquero R, 2000, Open femur fractures in children: treatment, complications and results, $J$ Pediatr Orth, 20,2, 183-8.

10. Jacob E, Settestrom JA, Durwood E, Bach E, Heath JR, Lawrene M, 1991, Evaluation of Biogradable Ampicillin Anhydrate microcapsules for local treatment of experimental Staphylococcal osteomyelitis, Clin Orthop Rel Research, 267, 237-44.

11. Jovanović $B$, Milošević V, Mazić $N, 2003$, Incidence rate of nosocomial infection in the intensive care unit of the clinical center of Serbia, Acta Clin, 3,1, 18-28.

12. Klemm KW, 1988, Gentamicin-PMMA Chains (Septopal chains) for the local antibiotic treatment of chronic osteomyelitis, Reconstr Surg Traum, 20, 11-35.

13. Leassus J, Tulikora I, Konttinen YT, Santavirta S, 2000, Treatment of infection and non-union after bilateral complicated proximal tibial fracture, Ann-Chir-Gynecol, 89,4, 325-8.

14. Mackey $D$, Varlet A, Debeaumont $D, 1982$, Antibiotic loaded Plaster of Paris pellets: an in vitro study of possible method of local antibiotic therapy in bone infection, Clin Orthop, 167, 263-8.

15. Nelson DR, Buxton TB, LuU QN, Rissing JP, 1990, An antibiotic resistant experimetal model of Pseudomonas osteomyelitis, Infection, 18 4, 246 -8.

16. Norden CW, Kennedy E, 1970, Experimental osteomyelitis I. Description of the model, J Infect Dis, $122,410-8$.

17. Norden CW, 1978, Experimental osteomyelitis. V. Therapeutic trials with oxicillin and sisomycin alone and combination, $J$ Infect Dis, 137,2,155-60. 
18. Norden CW, Meyerwitz RL, Keleti E, 1980, Experimental osteomyelitis due to Staphylococcus aureus or Pseudomonas aeruginosa: A radioogaphic-pathological correlative analysis, $B r J$ Exp Path, 61, 451-60.

19. Norden CW, Shinners $E$ 1985, Ciprofloxacin as therapy for experimental osteomyelitis caused by Pseudomonas aeruginosa, J Infect Dis, 151, 2, 291-4.

20. Nunmaker DM, 1998, Experimental models of fracture repair, Clin Orthop, 335, 56-65.

21. Passl R, Muller CH, Zielinski CC, Eibl MM, 1984, A model of experimental posttraumatic osteomyelitis in guinea pigs, $J$ Trauma, 24, 4, 323-7.

22. Perry CR, Pearson RL,1991, Local antibiotic delivery in the treatment of bone and joint infection, Clin Orthop, 263, 215-26.

23. Petri WH, 1991, Evaluation of antibiotic supplemented bone allograft in rabbit model, $J$ Oral Maxilofac Surg, 49, 392-6.

24. Rissing JP, Buxton TB, Weinstein RS, Shockley RK. 1985, Model of experimental osteomyelitis in rats, Immun, 47:581-6.

25. Sweetman SC (ed), 2002, Martindale. The Complete Drug Reference,33ed, Pharmaceuticals Press, London, Chicago, 192, 230-2.

26. Sisk TD, 1987: Fractures of lower extremity, In Crenshaw AH (ed) Campbell's Operative Orthopaedics, C.V Mosby Co, St Louis, Washington, Toronto, Vol.III :1607-718.

27. Walenkamp GHIM, Vree TB, Van Rens TJG, 1986, Gentamicin-PMMA beads. Pharmakocinetic and nephrotoxological study, Clin Orthop, 205,171-83.

\title{
ARTEFICIJALNI OTVORENI PRELOMI TIBIJE LEČENI KLOKSACILINOM
}

\author{
LEŠIĆ A, BUMBAŠIREVIĆ M, BUMBAŠIREVIĆ V, KRSTIĆ N i TATIĆ V
}

\section{SADRŽAJ}

Na modelu arterficijalnog preloma potkolenice pacova i posle arteficijalne kontaminacije sa Staphylococcus aureus-om, u cilju sprečavanja duboke infekcije kostiju primenjene su tri metode lečenja antibiotikom Kloksacilinom: 1 kombinovana intramedularna I parenteralna terapija koja je poređena sa: 2 . samo intramedularnom i 3. samo parenteralnom terapijom Kloksacilinom.

Intramedularna inokulacija $15 \mathrm{mg}$ Kloksacilina (rastvorenog u vodi) u toku hirurškog zbrinjavanja preloma i postoperativnog parenteralnog lečenja istim antibiotikom u dozi od $50 \mathrm{mg} / \mathrm{kg}$ dnevno u toku 14 dana, sprečila je nastajanje stafilokokne infekcije kod svih životinja $(n=21)$. Samo parenteralnim lečenjem Kloksacilinom postignut je terapijski efekat posle 42 dana davanja u dozi od $50 \mathrm{mg} / \mathrm{kg}$. Jednokratnom, intramedularnom aplikacijom $15 \mathrm{mg}$ vodenog rastvora Kloksacilina nije u potpunosti sprečena stafilokokna infekcija. Ova terapija bila je uspešnija do 28 -og postoperativnog dana (16,6\% pozitivnih nalaza S.aureusa, u odnosu na $40 \%$, 42-og dana posle operacije).

Makroksopski, radiološki i histološki promene na operisanoj potkolenici pacova bile su u skladu sa efektima primenjene terapije. Rezultati naših istraživanja ukazuju da kod otvorenih preloma potkolenice uz parenteralnu terapiju, intramedularna aplikacija antibiotika, zbog direktnog delovanja u kontaminiranoj povredi, u prvim postoperativnim danima sprečava razvijanje infekcije i skraćuje period parenteralne terapije. 